\title{
International cooperation Brazil-Cuba-Haiti: the role of community radios in strengthening social mobilization in the public health context in Haiti
}

Renata Machado dos Santos Gomes ${ }^{1}$

Valdir de Castro Oliveira ${ }^{2}$

${ }^{1}$ Secretaria de Atenção à Saúde, Ministério da Saúde. Esplanada dos Ministérios Bloco G, Zona CívicoAdministrativa. 70058-900 Brasília DF Brasil. renata. msgomes@saude.gov.br

${ }^{2}$ Programa de Pós-

Graduação Stricto Sensu em Informação e Comunicação em Saúde. Instituto de

Comunicação e Informação Científica e Tecnológica em Saúde. Fundação Oswaldo Cruz.

\begin{abstract}
The present article investigates the role of Haitian community radios in strengthening social mobilization, with the aim of supporting the actions undertaken in the field of public health in Haiti, based on the development of the Workshop for community radios, as part of the Tripartite Cooperation Brazil-Cuba-Haiti. The qualitative methodology is justified because of the study content, an analysis of documents and direct observation, through a case study presented at the Workshop held in the department of Hinches, in Haiti. This meeting was held in the context of the Working Group on Tripartite Communication, under the responsibility of the Health Channel/ Fiocruz, in partnership with the Department for Health Promotion and Environmental Prevention of the Ministry of Health and Population of Haiti (DPSPE/MSPP/Haiti), with a proposal to better structure a network of multipliers in health promotion.
\end{abstract}

Key words Health; International cooperation, Social mobilization, Community radios, Haiti 


\section{Introduction}

In January of 2010, the foundation of a country already shattered by authoritarian regimes, faced with a scarcity of resources and precarious health underwent one more blow: the earthquake. Thousands of people ended up without shelter, hundreds died and many more are deemed to have disappeared. Faced with this reality, in May 2010, Brazil signed a health cooperation agreement, four months after the disaster. The Cooperation, considered horizontal - between developing countries - represented a donation from the Brazilian Government of R $\$ 135$ million reals ${ }^{1}$ for the reconstruction of the Haitian health system, called Tripartite Cooperation Project Brazil-Cuba-Haiti, one of Brazil's largest investments in humanitarian aid. It was about “(...) more than rehabilitating the structures torn down by the earthquake, a true reconstruction of the system to make it ever-more apt to service the needs and expectations of the Haitian population"2. Support to strengthen the health system in Haiti is one of the priority initiatives, part of the $14^{\text {th }}$ strategic goal of the Brazilian Health Ministry 2011-2015 . As a guideline, the Cooperation has the aim of strengthening Brazilian presence in the international scenario, with the purpose of expanding its presence in the United Nations agencies and health programs, and cooperate with the development of health systems in the countries of South America, Central America and the Community of Portuguese Speaking Countries - CPLP [acronym in Portuguese] and Africa ${ }^{4}$.

In Brazil, the Health Ministry, through the mediation of its Special Advisor in International Matters (Aisa/MS), is responsible for the articulation involving three federal institutions: the Fundação Oswaldo Cruz (Fiocruz), the Universidade Federal do Rio Grande do Sul (UFRGS) and the Universidade Federal de Santa Catarina (UFSC). At the Fundação Oswaldo Cruz, coordination of technical actions as part of the Cooperation Project Brazil-Cuba-Haiti is under the responsibility of the Center for International Relations (Cris/Fiocruz). This project has the mission to strengthen the Haitian Health System. At Fiocruz, the Escola Nacional de Saúde Pública Sergio Arouca (Ensp/Fiocruz), the Instituto de Comunicação e Informação Científica e Tecnológica em Saúde (Icict/Fiocruz) and the Canal Saude/Fiocruz are involved in the planning and execution of projects with Haiti, with the participation of Cuba.

The Workshop on Community Radios in Haiti, organized by the Canal Saúde/Fiocruz, counted upon the partnership of the World Association of Community Radio Broadcasters in Haiti (Amarc/Haiti) and of the Direction for Health Promotion and Environmental Prevention of the Health Ministry and Population of Haiti (DPSPE/MSPP/Haiti).

In 2010, the Canal Saúde, a permanent Project of the Presidency of the Fiocruz Foundation, that since 1994 produced its programs and aired them through partner stations, was granted status of a radio station, through the hiring of a satellite space with $\mathrm{C} 2$ reception, thus having its own airing space. Invited in May 2011 by the Centro de Relações Internacionais of Fiocruz, the Canal Saúde/Fiocruz took on the challenge to act in benefit of health promotion in Haiti, articulating actions in Health communication. Two months after the first meetings, it went on a trip to map the reality of communications in the city most affected by the earthquake, the capital Port au Prince.

Despite the Canal Saúde expertise in audiovisual communication, the trip to Haiti sensitized and further ratified, for the professionals sent there, that it was indispensable to include community articulation with community radios in the plan, considering the broad reach of radio frequencies, compared to the 100 watts of power and the existence of over 35 community radios connected to Amarc/Haiti throughout the country.

Considered radical media, community radios have their power source in popular culture, the 'oxygen' that keeps them alives. This type of media comes ever closer to the common citizen, to the people, the community, and therefore refers to a strategic communication tool in health. The Workshop on Community Radios, in August 2012, was the first meeting held by Canal Saúde/ Fiocruz with community radios associated to Amarc/Haiti, selected by DPSPE/MSPP/Haiti. Overall, 20 radios sent professionals to represent them. Amidst the expectations and conflicts, a national partnership arose, whose construction is the focus of analysis of this article, based on a qualitative approach.

\section{Methods}

The qualitative approach guided the survey through a specific case study: the workshop on community radios in Haiti, held in August 2012, coordinated by Canal Saúde/Fiocruz in partnership with DPSPE/MSPP/Haiti, and support from CRIS/Fiocruz and ICICT/Fiocruz, as part of the Working Group on Communication from the 
Tripartite Cooperation Project Brazil-Cuba-Haiti. The workshop was held during 14 days, from 9:00 a.m. to 5:00 p.m., every day, except Sundays. The study involved direct observation, documental analysis and a literature review, becoming a social evaluation.

Following this outlook, under the guidance of a case study as described by Minayo ${ }^{6}$, the present study used a variety of information sources and a chain of evidence on the fundamental role of communication for health. More specifically, the role in health promotion, an articulation that is elementary in the process of activities shared by Canal Saúde/Fiocruz, MSPP/Haiti and community radios in Haiti. This because the Health and Population Ministry of Haiti (MSPP/Haiti) considers communication a strategic area in health promotion actions. So much so that the health communication coordination for the MSPP/Haiti belongs to the Direction of Heath Promotion and Environmental Prevention (DPSPE) of the MSPP/Haiti.

Communication is based on the recognition of the other; of an agent that dialogues with the diversity expressed in the beliefs, values, language, in their voice. It is the population taking ownership of means and information to build their knowledge in health, aware of the hegemonies that silence conflicts and efface plurality ${ }^{7,8}$. Under this perspective, communication involves structuring ties, based on a network of players, disciplines and institituions ${ }^{9}$.

Silva Junior and Mascarenhas ${ }^{10}$ remit to this concept the meaning of accountability, affectivity, therapeutic relation and continuity. The connection attracts, commits, mobilizes the players involved to cooperate or not, to favor an ideal; enables a process in which conflict is inherent. Along this path, the connection builds, destroys and rebuilds ties, creating a bridge of solidarity ${ }^{11}$, or a gulf between the bodies. Negotiation and conflict mediation are strategies that should permeate all forms of this connection, because the differences in social brackets, race, sexual orientation, diversity of thought, of feelings and opinions will make themselves present and permanent. Herein lies the art of these ties: to draft collective projects, converge intentions ${ }^{12}$, even in the face of diversities and adversities.

In the Haitian context, radios move in the symbolic space of the nation, articulating the world of imagination, opening the way for interlocution. As we will see further ahead, there are intrinsic characteristics of radios, such as oral language, the penetration, the mobility, the low cost, the sensoriality and autonomy, among others, that leverage their use in spaces in which economic, geographic and cultural difficulties are inherent ${ }^{13}$, as in Haiti.

\section{The role of radios}

Faced with this perishable word, radios involve listeners that hold it as something close to them. Radios participate in their day-to-day, in their pain, as an extension of themselves, of their own body. Marshall Mclhuan ${ }^{14}$ had already emphasized the power of the spoken word, when he stated that this one is able to involve all of the senses. According to him, radios are a cold medium, with low definition because they offer little, and the listener has to fill a lot ${ }^{14}$.

It is necessary for listeners, interlocutors, to create, imagine, make words concrete through their context, their uniqueness, expectations and experiences, and because of this, they are interlocutors: they take part in the process of building meaning, as described by Barktin ${ }^{15}$. For him, "the meaning is not in the word nor in the soul of the speaker, as it is also not in the soul of the interlocutor. It is the effect of the interaction of the speaker and the receptor produced through the material of a specific sound complex"15. In fact, radios are an extension of the central nervous system, in Mcluhan $^{14}$, which means they are equivalent to human speech itself. It is the sensoriality provided by radios that, according to Ortriwano ${ }^{13}$, makes it possible to create a 'mental dialogue', spurs the imagination "through the emotionality of words and sound modelling resources"13.

From the communication viewpoint, radios make it possible to air information rapidly and simultaneously with the events, dispense with the literacy of listeners, besides being available 24 hours a day, granting it the special power of reaching different types of audiences and of being a vehicle that potentially mobilizes social groups or audiences. This is due to its capacity to influence people and interfere in the social agenda, especially in the more popular social brackets ${ }^{13}$.

In the field of aesthetic production, radios seek simplification, through voice and sound effects, and music. Free of the cables, plugs, technology that made portability possible ${ }^{16}$, generating autonomy ${ }^{13}$. Faced with the absence of an image, they permanently exercise their concern in captivating the listener's attention. For this purpose, repetitions are elementary, because while people listen to the radio, these receptors can walk, run, write, cook, clean, perceive, inter- 
act with the environment; that is to say, they are inert in the midst of their surroundings. All of this because the radio's mobility, its lower technological complexity. Radios move along with stations and receptors, which allows them to be present in more diversified spaces.

Add to this oral language - one of the greatest virtues of radios: listeners do not need to be literate to have access to the messages broadcast. A priori, this is the audience that is eliminated in printed media. In television, a great deal of the information passes by unidentified for illiterate people ${ }^{13}$. In that same perspective, Nunes ${ }^{17}$ highlights that in oral cultures, the redundancy and repetitions keep the speaker and the listener in the same wavelength, multiple spoken languages dialogue, with an overlapping of signs, an enhanced outlook due to the presence of an integrating medium, such as the radio. An instrument of mediation that builds reciprocity and that even when faced with discontinuity, social and economic fragmentation, makes it feasible to create networks, oriented by social capital ${ }^{18}$. It is evident that this concept is intrinsically linked to the connection, the ties, lines of compatibility or incompatibility. If this understanding is pegged to the purpose of existence of community radios, the reach potential goes beyond the physical limits of frequency, even in the face of weak connections imposed by physical, social, behavioral, religious distance, among others, but still respected as part of the collective. Because any order of living together is built ${ }^{19}$.

In this sense, we can foresee the potential of radios in the construction of imagination world in the population's horizon. Because it is in the field of feeling, of emotions that media, including radios, opens up its claws, exerts power, persuades, convinces, manipulates, as expressed in the first dictatorships of the $20^{\text {th }}$ century, where radios were the vehicle of communication par excellence. However, on the other hand, these same feelings can allow for an emancipatory power, autonomy, and liberation. What should be stressed, however, is that in both cases there has to exist the social connection, interaction, social and existential insertion of the individual ${ }^{8}$.

Meditsch ${ }^{20}$, upon remembering Orson Welles radio broadcast, The War of the Worlds - a text adapted from the book of the English author Herbert George Wells by Howard Koch - elucidates, with emphasis, another of the radios' peculiarities and that can be of use for private or collective interests: the impression of reality. Under that perspective, the first" radio, as highlight- ed Zaremba ${ }^{21}$, arose at the end of the $19^{\text {th }}$ century and was recognized as a communication system that was born in that crossroads of sound and visual signals, broadcasting messages through electromagnetic waves. However, the popularization of radios began only during the 1920's, with the first regular radiobroadcast service launched in the USA ${ }^{22}$. In 1932, in his theory about radios, Brecht attributed to radios the perspective of an integrating media, as if they were transformed from a distribution device into a communication device, the listener would also become an interlocutor, specifying that radios should be a strategic means to set up democracy, the citizens'space ${ }^{23}$.

Additionally, what had been consolidated was a hegemonic system, "an institutionalized complex of interdependent information means, with a trend to homogenizing its messages" ${ }^{24}$. Nevertheless, alternatives to that capitalist system ${ }^{25}$ arise and become committed to change. The role of community radios, in the Haitian reality, reflects that unique aspect of radios in communities, with that permanent search to understand the other, to shares values, ideas and behaviors in a communal profile and not an individualistic or mechanistic on $e^{26}$. Because man is communication, a being of contacts, and radios should be a subject of his/her learning, not an object ${ }^{27}$. For this reason, in this article there is a brief reflection on the defense of knowledge, which is relative, in essence compassionate, expressing the struggle against the 'kidnap of community speech ${ }^{28}$.

\section{Radios in Haiti}

Radios are the vehicles with the greatest audience levels in Haiti, mainly due to three characteristics of this vehicle: its low cost, its penetration potential and emphasis on spoken language. The advantage of oral language, as already highlight$\mathrm{ed}$, is that to receive the message it is merely necessary to listen ${ }^{13}$. In Haiti, this peculiarity is fundamental for the success of radio audiences, because according to the Institut Háitien de Statistique et d'Informatique ${ }^{29}$, illiteracy rates are extremely high, reaching $19.5 \%$ in urban areas and $62.9 \%$ in rural areas. Considering that reality, radios are a strategic means to reach the population.

Because of this, community radios deserve to be highlighted, as they preserve the spoken language of the nation - $\mathrm{Kreyol}^{30}$ - during most of their broadcasts. As argued by Andrade Silva ${ }^{31}$, Kreyol represents the spoken language in Haiti, French is the language that they teach at school, 
and is part of the written culture ${ }^{31}$. In this scenario, community radios represent the living image, record and expression of collective and social memory, of the individual inserted in and inhabited by 'reference communities ${ }^{32}$.

Much beyond the importance of radio as a communication tool, lies the fact that dissemination can be done at a lower cost, demands less diesel, fuel used to produce the necessary energy for radio propagation, a reflection of the scarce energy production in the country. According to the Institut Háitien de Statistique et d'Informatique $^{29}, 68.5 \%$ of Haitian families use coal for cooking, This fact is allied to the precarious financial situation of a large parcel of the population, preventing television and other printed media to play that hegemonic role in the country. This place belong to radios, because the device that receives the broadcasts has a low cost, "and they are affordable and within the reach of a much larger part of the population"13.

The penetration potential is also an important characteristic of radios, taking into account the geographic singularities of the Haitian territory, with very uneven land. Radios are the most encompassing media, precisely due to this characteristic: they are able to reach the most remote sites and achieve national coverage. "At the same time, regionalism can thrive within them, as they have lower technological complexity and allow for the existence of local stations, that can broadcast messages that are closer to the listener's field of experience" ${ }^{13}$.

In accordance to Article 8 of the Haitian Constitution of 1987, the territory of the Republic of Haiti is made up of the western part of the island of Haiti and the adjacent islands of La Genebra, La Tortue, I'Ile à Vache, les Cayemittes, La Navase, La Grande Caye, This includes all of the other island in the territorial sea, delimited to the East by the Dominican Republic, to the North by the Atlantic Ocean, to the South and West by the Caribbean Sea or the Sea of the Antilles ${ }^{33}$.

Internally, the country is divided into $10 \mathrm{de}$ partments: Département de L'Ouest, Département du Sud-est, Département du Nord, Département de l'artibonite, Département du Nord-Est, Département du Centre, Département du Sud, Département de la Grande-Anse, Département du NordOuest, distributed throughout the $27,750 \mathrm{Km}^{2}$ of territorial unity ${ }^{29}$. Estimates for the population in 2012 were of 10,413,211 inhabitants, a reflection of the high fecundity rates: four children in rural areas and three in the urban ones, which points towards extremely young age bracket structures.
The last General Census of the Population and Housing of Haiti made available by the Institut Háitien de Statistique et d'Informatique ${ }^{29}$ was carried out in 2003, when the population was estimated at 8,373,750 inhabitants. According to the survey, over $60 \%$ of the population lives in rural areas. Only $8.5 \%$ of the households receive treated water. Workers are in essence autonomous (82.1\%), followed by far by "officials" $(12.7 \%)$ and health professionals $(2.2 \%)$. What predominates is the informal economy, and trade workers selling on streets. According to the International Labor Organization ${ }^{34}$, informal economy “(...) refers to all of the economic activities of workers and economic units that are not covered or encompassed by formal provisions, due to the legislation or to practice (...)".

Almost fifty per cent of the labor force in the country works together as "farmers and qualified workers in agriculture and fishery". Another $23.4 \%$ and $11.2 \%$, respectively, are employed as "service workers and workers in stores and markets" and as "artisans and similar workers in handicrafts." In the urban areas, among those who are employed, some work as "service workers or in stores and markets" (35.7\%) and others in "arts and trades relating to workers in handicrafts" (21.0\%), while in the rural areas, the majority of workers are rural workers (71.6\%). We underscore additionally the low rates of people with a university degree, that is of only $1.1 \%$ ( $1.4 \%$ of men compared to $0.7 \%$ of women). The population is deemed to be young, most of which, 35\%, are less than 15 years of age.

As this is the reality, radios are considered to be support in the struggle of Haitian communities for a better standard of living. As this is an oral culture, there is a public educational radio, created by a decree of the Haitian government on December 6, 1972, called Educational Radio. Regarding community radios, we had the privilege of receiving a document sharing the rich history of community radios in Haiti.

The genesis of radios in Haiti is described in this book, celebrating the 20 years of Sosyete Animasyon Kominikasyon Sosyal, better known as $\mathrm{SAKS}^{30}$. According to the document, radios are the "main communication tool of the Haitian people"35: Community radios represent the great resistance of Haiti. According to the SAKS book, this movement had its origin in Bolivia and in Colombia, in $1940^{30}$.

Notwithstanding this, there is no certainty regarding the exact moment for the coming into being of the first community radio in Haiti. Some 
of the first experiences recorded are described in the document sent by SAKS ${ }^{30}$, very kindly released for the present study. Considering this trajectory, the importance of SAKS should be underscored in the effective integration of community radios in Haiti. Created in 1992, SAKS fights for the democratization of communication in the country and is connected to the World Association of Community Radio Broadcasters (AMARC).

SAKS' commitment is to foster the right to information, supporting "community radios as a means for popular communication, for profound social change, alternative development, the advent of a true democracy and reconstruction"35 (translated from Spanish into Portuguese by the author of the article). Challenges are countless, especially those that arose after the wake of the earthquake in January 2010, when SAKS had its "infrastructure, equipment and materials for many radios destroyed by the earthquake." ${ }^{35}$ (translated from Spanish into Portuguese by the author of the article). Furthermore, persecution of community radios is quite frequent. With the aim of guaranteeing freedom of popular communication, and to give legitimacy to the movement, SAKS launched the foundation for a draft proposal, for a bill on community broadcasting, in 2007. This continues to be a live struggle, as in Haiti there is still no law that can regulate community radio broadcasts ${ }^{30}$.

SAKS is a partner of over forty community radios and has two community radio projects in communities - Petit Goave and Ile à Vache. Since it was founded, SAKS supported the opening of various community radios and participates in a movement favoring community radios in Haiti and that works, mainly in advocacy of social movements, with a collective approach. The purpose is the construction of a solidarity network mediated by the creation of an alternative communications network. It claims financial independence for community radios, as a public good. The objective is that "community radios become engaged in the popular democratic fight, and not be the property of a religious sector or of other funding agencies" ${ }^{\prime 30}$.

\section{Workshop on Community Radios in Haiti}

The Canal Saúde/Fiocruz organized a workshop for community radios, through a partnership with the DPSPE/MSPP/Haiti and with AMARC/Haiti, with the support of the Centro de Relações Internacionais and the Instituto de Comunicação Científica e Tecnológica em Saúde, both from Fiocruz. Initially, contact was made with AMARC/Brazil with the goal of finding a professional with experience in acting with community radios, connected to AMARC - and with the same methodological base - one that could speak French.

Founded in Canada, the World Association of Radio Broadcasters exists since 1983. This is an international non-government, lay non-profit organization made up of a network of more than four thousand community radios, Federations and allies, present in over 115 countries. The defense of the guarantee of diversity and plurality in radio broadcasting and in audiovisual communication services and particularly the democratization of communications are elements that are part of its mission ${ }^{36}$.

The Workshop brought together 20 journalists from 20 different community radios, two representatives from each of the 10 departments of Haiti. The event was held in the department of Hinches, three hours away from the capital, Port au Prince. The choice of this location for the event fell under the responsibility of DPSPE/MSPP/ Haiti, justified by the wishes of the Ministry of Health and Population to move to the hinterlands with its actions, as a way of guaranteeing the permanence on site of all of the professionals, during the 14 days that were foreseen for the workshop.

The goals of the workshop were to increase awareness, mobilize and operationalize Haitian radio broadcasters from the 10 departments in the country, to approach topics in health, as part of the programs of community radios in which they were active (two radios per department). Additionally, efforts were made to articulate a network of community radios, as support to actions in health promotion by the DPSPE/MSPP. These were the goals of the meeting ${ }^{37}$. During the classes, despite the strong political motivation that the professionals claimed to have, what was observed was that few had knowledge of the technical terms, and the difference between the models for programs used in radiobroadcasting, issues that were tackled during the period in which the workshop was held.

The workshop was organized in two stages. The first lasted six days and concentrated on the presentation of a tripartite cooperation project and strategic planning of the DPSPE/MSPP/Haiti, debates relating to health topics and the environment and neglected diseases, epidemiologic surveillance, a broader health concept, health promotion and the presentation and discussion of different radiobroadcasting formats. 
Radio broadcasters worked to identify the difficulties relating to the Haitian reality, by working in three different work groups: Great South, Great North and Center. The highlights referred to how hazardous information can be if not adequately matched to the local reality. The report was that there are health units that are very remote, where it would take three days for a Haitian citizen to get to. This revealed the multiple obstacles in Haiti: poverty, difficulties in displacement, passivity of the society and a precarious access to internet. The importance of working with information before communicating it to listeners was also mentioned. It had to be clear that radio broadcasters could not treat the ill person, but could leverage health promotion, airing information and seeking help.

Regarding this aspect, direct contact with listeners was deemed to be important, and opened up questioning about which radiobroadcasting formats each radio works with, and the mechanisms they use to integrate to a community. The importance of the presence of the Ministry of Health and Population of Haiti was emphasized, for a better approximation to community radios. What the teams from the Canal Saúde observed was that radio broadcasters, in their great majority, had no academic training and acted as volunteers in their community radios ${ }^{37}$.

The second stage of the workshop consisted of a discussion about the participants' experience, as well as practical exercises for the production of different radiobroadcasting pieces. Participants split up in groups and began to draft thematic pieces: on HIV/AIDS, malaria, cholera, tuberculosis, communication in health, child exploitation, garbage, drugs, among others, with each group approaching a different topic. One approach that stood out, that is common practice, is to give to another person back his/her own role, leveraging the development of autonomy ${ }^{38}$.

Under this perception, radio professionals worked with several different group dynamics. There was the exhibition of some documentaries, among which a campaign against cholera. Ensuing this, several jingles were presented for the fight against AIDS, speaking about the use of condoms, in five rhythms: axe, baião, brega, pagode and rock, focusing on which public would potentially receive each different rhythm. Spots were presented as a continuity of the debate on these themes: "a female condom", "World Soccer Cup", "safe sex" and "conscious members of funk".

When it came to tuberculosis, three spots were presented, role- playing, the first with symptoms of tuberculosis, prevention and ways of offering treatment; the second, warnings on the symptom of persistent coughing, the importance of getting information and resorting to the health center, and the last was a compilation of both. Afterwards, a debate was proposed, with three members at the debate table, a mediator and two professionals in production.

During the workshop, there were some moments for participants to evaluate the process. Members spoke about the moment and the opportunity of socializing, because formerly the great majority did not know each other and they were now together and had become friends. They thanked the Tripartite Cooperation, the coordinators and organizers of the event, for the participative method, allowing Haitians to share their knowledge and experiences. They recognized that community radios are the basis for popular organization and that music is a strategy that can bring people together, besides mentioning the interests shared in this group. This is how the topic of inclusion was dealt with.

Another activity to motivate the group was the one that worked with questions on "what I like to listen to on radio", "what I think I should do on radio" and "which would be the radio of my dreams". These fundamental issues approached included themes such as: infrastructure, financing, regulations, programming and audience. Radio broadcasters put together a list of the urgent topics in radio programming, raising topics such as the rights of children, of women, of the elderly population, as well as issues that guide agriculture and the health of physically handicapped persons.

The following activity involved practicing interviews for the radio. Journalists split up in pairs, the interviewer and interviewee. Each interviewee chose his/her theme, described as follows: mother's day, cholera, youngsters, female violence, children, environment, violence against people and immigration. The following activity involved carrying out a survey about some diseases, among which were: malaria, tuberculosis, cholera, Aids, syphilis, diarrhea and even violence against women, sickle cell disease, immigration, typhoid fever, environment, mental health, vaccination, chigoe flea, diabetes, hypertension and rabies. A talk show, a debate and a round table were put together, each group was responsible for one of the formats. According to the Canal Saude, these exercises resulted in five pilot programs, 20 minutes each. All of the participants took all five taped programs to their community 
radios on a pen drive, so they could be aired by the 20 radios (from the 10 departments) represented at the workshop.

At the end of the workshop, the Canal Saúdel Fiocruz suggested a plan to articulate with community radios, for the epidemiologic surveillance plan developed through the Tripartite Cooperation Project Brazil-Cuba-Haiti, allowing for social-cultural and departmental diversity to be respected, and to serve as a guide in the construction of health communication material produced by radios. The idea is to involve epidemiologists and communication officials from each department with the professionals from the community radios that have already been trained and sensitized, with the proposal to create a link, under the coordination of the DPSPE/MSPP/Haiti.

\section{Final Considerations}

Faced with the context of extreme poverty, political violence and catastrophes, besides an oral culture, radios are vehicles that have the ability to mediate conflicts, minimize pain and foster an enhancement in health conditions, in life; by building images that can generate hope and fundamentally mobilize the population to face its problems. Radios are the main mediators of information and culture in Haiti. Community radios represent the voice of the community, the vehicle through which the peoples can express themselves, interact, mediate their demands, preserve their values, their memory, and their history, besides giving legitimacy to the popular movement.

In this scenario, the philosophy of the radiobroadcasting workshop was to explore the potential of radios as an educational vehicle, for the exercise of citizenship, one able to motivate a change of practices, even in the field of health. Radios use oral language, tell stories that are not static: it is necessary to remind the listener at each instant of the topic that is being debated. The best results are obtained through the construction of short phrases, simple and clear. Speaking very quickly, clearly and precisely, with agility, articulated with reality, with facts.

Participants at the workshop kept their engagement during the entire course, with the expectation of taking back with them this construction, shared, negotiated, integrating knowledge and practice, an exchange of experiences, of health, generating life, that is, a gift. In a country where natural disasters are frequent, means of communication are the engine that lever- ages mobilization, prevention, the redemption of confidence in the face of so many risks and vulnerability. In Haiti, radios help in the reconstruction of a country that is a "work quarry". Broadcasts from community radios can transversally permeate actions in health and contribute to supporting the capillarity of actions, with a view to rebuilding the national health system in Haiti.

There is a sense of urgency to rethink guidelines for the execution of the Project drafted through the Brazil-Cuba-Haiti partnership, making manifest the priority for Brazilian professionals to listen to the real needs of health professionals in the MSPP, and for the professionals in communication in the context of Haitian community radios. While mobilizing the promotion and prevention network, the peculiarities of the Haitian territorial extension should be made known, in terms of the acute lack of health assistance. A diagnosis offers subsidies for an emergency approach geared to priorities, but one that will foresee projects for the medium and long terms, in a pro-active movement that will preserve the culture, but leverage actions to overcome inequities and make health promotion in the country effective.

For the Direction in Health Promotion and Prevention of the Environment (DPSPE/MSPP), in this context, the Haitian "basic unit offices" of the MSPP/Haiti, the "UCS Bureau", whose purpose is that of regionalizing actions and services in health, by decentralizing, are strategic spaces, allied to the work in partnership with community radios. They appear as artisans, architects of the ties that allow for adherence and breadth in health actions, motivating autonomy and creativity in health care. Vehicles of expectations and hope. Mediators for the construction of policies aimed at fostering access to health information for the population, and articulated with demands for services and with standards of quality of life ${ }^{39}$ defined by Haitians themselves.

Community radios therefore constitute the instrument to redeem the space for expression for Haitian peoples, attesting to their memory and identity. A mechanism to induce change and transformation in the public health context in Haiti. A power able to mobilize the population of Haiti in a permanent way. These are thoughts that were recompiled at the First Workshop on Community Radios from the Tripartite Cooperation Project Brazil-Cuba-Haiti, whose greatest value is the record of a collective narrative - albeit partial and limited - in which experiences and shared moments with their wealth and contradictions are highlighted ${ }^{40}$. 


\section{Collaborators}

RMS Gomes and VC Oliveira participated in all of the stages of the drafting of this article.

\section{References}

1. Brasil. Presidência da República. Casa Civil. Subchefia para Assuntos Jurídicos. Lei 12.239, de 19 de maio de 2010. Diário Oficial da União 2010; 20 maio.

2. Brasil. Ministério da Saúde (MS). Assessoria Internacional do Ministério da Saúde. Cooperação Saúde: boletim da atuação internacional brasileira em saúde. Brasília: MS; 2010.

3. Brasil. Ministério da Saúde (MS). Secretaria-Executiva. Departamento de Monitoramento e Avaliação do SUS. Planejamento estratégico do Ministério da Saúde: 2011 2015: resultados e perspectivas. Brasília: MS; 2013.

4. Brasil. Ministério da Saúde (MS). Assessoria Internacional do Ministério da Saúde. Ciclo de Debates. Participação do Ministério da Saúde no Cenário Internacional da Saúde. $1^{\circ}$. Ciclo - Integração Regional e Saúde. Brasília: MS; 2009.

5. Downing JDH, Ford TV, Gil G, Stein L. Mídia Radical: rebeldia nas comunicações e movimentos sociais. $2^{\mathrm{a}} \mathrm{ed}$. São Paulo: Editora Senac São Paulo; 2004.

6. Minayo MCS. O Desafio do Conhecimento: pesquisa qualitativa em saúde. 11a Ed. São Paulo: Hucitec; 2008.

7. Oliveira VC. Os Mídias e a Mitificação das Tecnologias em Saúde. In: Pitta AMR, organizador. Saúde e Comunicação/Visibilidades e Silêncios. São Paulo, Rio de Janeiro: Hucitec, Abrasco; 1995. p. 25-66.

8. Araújo IS, Cardoso JM. Comunicação e Saúde. Rio de Janeiro: Editora Fiocruz; 2007.

9. Sodré M. As estratégias sensiveis: afeto, mídia e política. Petrópolis: Vozes; 2006.

10. Silva Junior AG, Mascarenhas MTM. Avaliação da atenção básica em saúde sob a ótica da integralidade: aspectos conceituais e metodológicos. In: Pinheiro R, Mattos RA, organizadores. Cuidado: as fronteiras da integralidade. São Paulo, Rio de Janeiro: Hucitec, Abrasco; 2004. p. 241-257.

11. Durkheim E. A divisão do trabalho social. Lisboa: Editorial Presença; 1977.

12. Freire P. Pedagogia do Oprimido. Rio de Janeiro: Paz e Terra; 2005.

13. Ortriwano GS. A informação no rádio: os grupos de poder e a determinação dos conteúdos. São Paulo: Summus; 1985.

14. Mcluhan M. Os meios de comunicação como extensões do homem. São Paulo: Editora Cultrix; 1964.

15. Bakhtin M. Marxismo e filosofia da linguagem: problemas fundamentais do método sociológico da linguagem. 13a Ed. São Paulo: Hucitec; 2012.

16. Oliveira VC. Condições e contradições da utopia radiofônica comunitária. In: Prata N, organizador. O Rádio entre as montanhas. Histórias, teorias e afetos da radiofonia mineira. Belo Horizonte: Fundac; 2010. p. 171-192.

17. Nunes MV. Rádios comunitárias no século XXI: exercício da cidadania ou instrumentalização da participação popular? Moreira SR, organizadora. In: Desafios do rádio no século XXI. São Paulo, Rio de Janeiro: INTERCOM, UERJ; 2001. p. 233-250.

18. Matos H. Capital social e comunicação: interfaces e articulações. São Paulo: Summus; 2009.

19. Toro JB, Werneck NMD. Mobilização social: um modo de construir a democracia e a participação. Belo Horizonte: Autêntica Editora; 2004. 
20. Meditsch E. Entre Wells e Welles: o roteiro de Howard Koch pôs a guerra dos mundos na era do rádio. In: $\mathrm{Za}$ remba L, Bentes I, organizadores. Rádio Nova, constelações da radiofonia contemporânea, $V$. 3. Rio de Janeiro: UFRJ, ECO, Publique; 1999. p. 135-156.

21. Zaremba L. Ideia de rádio entre olhos e ouvidos. In: Zaremba L, Bentes I, organizadores. Rádio Nova, constelações da radiofonia contemporânea, $V$. 3. Rio de Janeiro: UFRJ, ECO, Publique; 1999. p. 14-30.

22. Calabre L. Rotativas no ar: o radiojornalismo. UFRJ, ECO 2005; 8(2):30-45.

23. Brecht B. Teorias de la radio (1927-1932). Revista de Economía Política de las Tecnologías de la Información y Comunicación; Mayo/Ago; 2003; V(2). [acessado 2013 maio 15]. Disponível em: http://www.vivalaradio.org/ medios-comunicacion/PDFs/MEDIOS_reflex2_brecht.pdf.

24. Sodré M. O monopólio da fala: função e linguagem da televisão no Brasil. Petrópolis: Vozes; 1984.

25. Leal S, Ribeiro LMR. Mídias alternativas e esfera pública: o espaço do debate político nas rádios comunitárias no Brasil e na França. In: Grupo de Trabalho: Mídia, Política e Opinião Pública. $30^{\circ}$ Encontro Anual da ANPOCS; 24 a 28 de outubro de 2006. Caxambu/MG. [acessado 2013 maio 30] Disponível em: http://www. anpocs.org/portal/index.php?option=com_docman\&task $=$ doc_view\&gid $=3315 \&$ Itemid $=232$

26. Luz MM. As rádios comunitárias como espaços contra -hegemônicos: entrevista com Raquel Paiva. [acessado 2013 abr 16]. Disponível em: http://www.seer.ufs.br/ index.php/eptic/article/view/96/68.

27. Freire P. Educação e mudança. Rio de Janeiro: Paz e Terra; 1979. Coleção Educação e Comunicação, V. 10.

28. Paiva R, Sodré M. O seqüestro da fala comunitária. Rio de Janeiro: ECO-PÓS; 2003. [acessado 2013 maio 15]. Disponível em: http://www.pos.eco.ufrj.br/docentes/ publicacoes/rpaiva_osequestrodafala.pdf.

29. Haiti. Instituto Haitien de Statistique et d'Informatique; 2003. [acessado 2013 maio 10]. Disponível em: http:// www.ihsi.ht/

30. Sosyete Animasyon Kominikasyon Sosyal (SAKS). L'expérience des radios communautaires en Haïti à partir des résultats de plusieurs évaluations effectuées de 2002 à 2007. Petyonvil: SAKS; 2012.

31. Andrade Silva F. Construções do "fracasso" haitiano [tese]. Rio de Janeiro: Universidade Federal do Rio de Janeiro; 2010.
32. Halbwachs M. A memória coletiva. São Paulo: Vértice; 1990.

33. Haiti. La République d'Haïti; 1987 Constitution de la République d'Haïti. Base de Donnés Politiques des Amériques. [acessado 2013 maio 16]. Disponível em: http://pdba.georgetown.edu/constitutions/haiti/haiti1987.html.

34. Organização Internacional do Trabalho. A OIT e a Economia Informal. O Trabalho Digno e a Economia Informal: resolução da $90^{\text {a }}$ Conferência Internacional do Trabalho; 2002. Escritório em Lisboa; 2005. [acessado 2013 maio 14]. Disponível em: http://www.ilo.org/ public/portugue/region/eurpro/lisbon/pdf/economia informal.pdf.

35. Estéus S. Apresentação. In: Sosyete Animasyon Kominikasyon Sosyal (SAKS). L'expérience des radios communautaires en Haïti à partir des résultats de plusieurs évaluations effectuées de 2002 à 2007. Petyonvil: SAKS; 2012

36. Associação Mundial de Rádios Comunitárias (AMARC). Princípios para um marco regulatório democrático sobre rádio e TV comunitária; 2009. [acessado 2013 maio 18]. Disponível em: http://www.amarcbrasil .org/amarc-principios-14-pontos-port.pdf.

37. Fundação Oswaldo Cruz (Fiocruz). Canal Saúde. Relatório da Oficina para Rádios Comunitárias do Haiti, Hinches/Haiti. Rio de Janeiro: Fiocruz; 2012.

38. Castoriadis C. A instituição imaginária da sociedade. Rio de Janeiro: Paz e Terra; 1982.

39. Minayo MCS, Hartz ZMA, Buss PM. Qualidade de vida e saúde: um debate necessário. Cien Saude Colet 2000; 5(1):7-18.

40. Minayo MCS. Análise qualitativa: teoria, passos e fidedignidade. Cien Saude Colet 2012; 17(3):621-626.

Article submitted 23/10/2013

Approved 27/03/2014

Final version submitted 05/04/2014 